\title{
食品の物性そして水一水分活性とガラス転移
}

\author{
熊 谷仁
}

共立女子大学家政学部食物栄養学科

\section{Physical Properties of Foods and the Effect of Water on Them -Water Activity and Glass Transition}

\author{
Hitoshi KUMAGAI \\ Department of Food Science and Nutrition, Kyoritsu Women's University, \\ 2-2-1 Hitotsubashi, chiyoda-ku, Tokyo 101-8437, Japan
}

\begin{abstract}
Water sorption isotherms give information on the interaction between water and solid components in foods. Using solution thermodynamics, the thermodynamic parameters of both water and solutes can be estimated. The integral Gibbs free energy, $\Delta G^{\mathrm{s}}$, is considered to be a suitable parameter for evaluating the interaction between solid and water from the thermodynamic point of view. The thermodynamic parameters obtained from water sorption isotherms relate to the degree of reduction in the glass transition temperature $\left(T_{g}\right)$, accompanied by water sorption. The difference between the chemical potential of solid (adsorbent) between a solution and a pure solid, $\Delta G_{\mathrm{a}}^{\mathrm{s}}$, which is obtained from water sorption isotherms by solution thermodynamics, is correlated well with $\Delta T_{\mathrm{g}}\left(\equiv T_{\mathrm{g}}-\right.$ $T_{\mathrm{g} 0}$; where $T_{\mathrm{g} 0}$ is $T_{\mathrm{g}}$ of dry material). This indicates that plasticizing effect of water on foods can be evaluated through the parameter $\Delta G_{\mathrm{a}}^{\mathrm{s}}$.
\end{abstract}

Keywords: water activity, glass transition, solution thermodynamics, GAB equation, plasticizer

1. 緒言

食品工学に扎いて物性が，プロセス設計，工程管理， 品質評価などで重要であることはいうまでもないが, 食品の物性は内部の水により大きな影響を受ける。ま た，食品中の水も他成分と複雑な相互作用をする。食 品の物性の研究をしていると水の存在のため物性挙動 が複雑になる (単純な理論式に合いにくい) ことを知り, 水の研究をしていると物性の問題に直面する.

2008 年に日本食品工学会誌に打いて「食品の物性そ して水」というテーマで，単位操作，物性論，計測手 法など食品工学に打ける様々な分野に関する解説論文 が 15 回連載された。筆者自身 4 回執筆（共著 3 回）し た [1-4] が，そのときには準備不足で執筆できなかっ た重要なテーマが「水分活性とガラス転移」である.

水分活性ないしは水分収着等温線 (等温での含水率 $v s$. 水分活性 $a_{\mathrm{w}}$ の関係） は，1970 年代には食品化学の 教科書にも記載がみられるポピュラーな概念であった。 水分収着等温線の物理化学的解析には，分子吸着モデ

(受付 2020 年 11 月 14 日，受理 2020 年 11 月 27 日)

₹ 101-8437 東京都千代田区一ツ橋 2-2-1 共立女子大学家政学部化学研究室

$\dagger$ Fax: 03-3237-2787, E-mail: kumagai@kyoritsu-wu.ac.jp
ルである $\mathrm{BET}$ モデルや $\mathrm{GAB}$ モデル（本稿の 2.2 で詳 述する）が用いられてきた[5]. 水分活性は，保存中の 食品中の劣化反応との関係（微生物による腐敗, 酸化, 褐変など）が整理されて打り[5]，現在でも食品の品質 管理において用いられる重要な概念である。ただ，水 分活性および水分収着等温線の概念においては，食品 中の水の存在状態は評価されているが，物性（劣化反 応にも影響するはずである）の概念は現れていない. ガラス転移は，1990代から，食品の製造・保存に関わ る様々な現象を説明できる概念として注目されてきた。 ガラス転移は試料全体の状態変化（ガラスからラバー へ）であり，水はあくまでガラス転移点 $T_{\mathrm{g}}$ を低下させ る可塑剈として扱われる。筆者は，水分活性（水分収 着等温線）からガラス転移への移行（水分活性が誤り という意味ではない）は，“パラダイムシフト”といえ るものと考えている.

本稿では，筆者の研究をもとに，水分活性とガラス 転移の関係について述べてみたい。なお, 本稿の内容は, 筆者の日本食品工学会の学会賞の受賞論文 [6] の一部と 内容が重複することを打断りしておく. 


\section{2. 水分活性と水分収着等温線}

\section{1 水分活性と水分収着等温線 $[6,7]$}

水分活性 (water activity) $a_{\mathrm{w}}$ は, 物理化学的には, 水の化学ポテンシャルから定義される水の活量 (activity) である．今，固体と水の 2 成分水溶液のギブ スの自由エネルギー (ギブスエネルギー) を $\widetilde{G}^{\mathrm{s}}$ とする $\left(\widetilde{G}^{\mathrm{s}}\right.$ の単位は $[\mathrm{J}]$ あるいは $[\mathrm{kJ}]$ である $)$ と，(水) 溶液 中の水の化学ポテンシャル $\mu_{\mathrm{w}}^{\mathrm{s}}$ は質量基準で, 以下のよ うに定義される。

$$
\mu_{\mathrm{w}}^{\mathrm{s}}=\left(\frac{\partial \widetilde{G}^{\mathrm{s}}}{\partial m_{\mathrm{w}}}\right)_{T, P, m_{\mathrm{a}}}
$$

ここで， $m_{\mathrm{a}}$ は固体の質量， $m_{\mathrm{w}}$ は水の質量， $P$ は圧力, $T$ は絶対温度である. 水の活量 $a_{\mathrm{w}}$ (水分活性) は，水 の化学ポテンシャルを用いて以下のように定義される.

$$
\mu_{\mathrm{w}}^{\mathrm{s}}-\mu_{\mathrm{w}}^{*}=R^{\prime} T \ln a_{\mathrm{w}}
$$

ここで $R^{\prime}$ は水の質量基準で表した気体定数 $(=0.462$ $\mathrm{kJ} /(\mathrm{kg}$ of water $\cdot \mathrm{K}), T$ は絶対温度, $\mu_{\mathrm{w}}^{*}$ は溶液と同一温 度 $(T)$, 同一圧力 $(P)$ に打ける純水の化学ポテンシャル である.このように水分活性の熱力学的解析に打いて は, 熱力学的関数を質量基準で表す方が便利である. また，「(水) 溶液」とあるが，固体 (adsorbent）への 水分収着によって形成される凝縮相 (condensed phase）を溶液とみなしている.つまり,均一な相 (phase) をなす “含水物質”を「(水) 溶液」と考えるのである. 今，水側の自由エネルギー（ギブスエネルギー）変化 $\Delta G_{\mathrm{w}}^{\mathrm{s}}$ を以下のように定義する.

$$
\Delta G_{\mathrm{w}}^{\mathrm{s}}=\mu_{\mathrm{w}}^{\mathrm{s}}-\mu_{\mathrm{w}}^{*}
$$

(1) 式, (3) 式から, $\Delta G_{\mathrm{w}}^{\mathrm{s}}$ は $[\mathrm{J} / \mathrm{kg}$-water] (あるいは $[\mathrm{kJ} /$ $\mathrm{kg}$-water]）の単位をもつ。（2）式，（3）式より，以下 の式が得られる.

$$
\Delta G_{\mathrm{w}}^{\mathrm{s}}=R^{\prime} T \ln a_{\mathrm{w}}
$$

気体を理想気体とすると， $a_{\mathrm{w}}$ は以下のように，溶液 の平衡状態に打ける相対水蒸気圧に等しくなる.

$$
a_{\mathrm{w}}=p_{\mathrm{w}} / p_{\mathrm{w}}^{\circ}
$$

ここで, $p_{\mathrm{w}}$ は溶液, $p_{\mathrm{w}}^{\circ}$ は純水の飽和水蒸気圧である. 食品科学では，(5) 式の右辺の相対蒸気圧を水分活性と よぶ.

水分活性 $\left(a_{\mathrm{w}}\right)$ と平衡含水率 $(\mathrm{W}$; 以下，単に含水率と いう）との関係を示したのが水分収着等温線である. 食品への水の収着挙動を水分収着等温線として整理す ることにより，特定の含水率における水と固体の相互 作用について定性的な情報が得られる。水分収着等温 線を用いて，保存中の食品中の劣化反応との関係も整 理されている。

\section{2 水分収着等温線と分子吸着モデル [5]}

水分収着等温線から水の存在状態に関するより定量 的な情報を得るには，吸着平衡理論を用いた解析を行 う。吸着平衡理論には大きく分けると，ポテンシャル 理論と分子吸着モデル（理論）とがある。ポテンシャ 儿理論は，吸着質（adsorbate，吸着する分子，ここで は水に相当）と吸着剤（adsorbent，吸着される物質， ここでは食品の固体成分に相当）との間のポテンシャ 儿の形を仮定して導かれる。一方，分子吸着モデルは， 分子の吸着様式を仮定して導かれ，一定温度における 単位質量（もしくは単位体積）当たりの物質 (吸着骫) への分子 (吸着質) の吸着（収着）量 $W$ を気体の圧力 $p$ の関数として表す．ここでは，代表的な分子吸着モデ ルについて述べる。な打，ここでは気相吸着の式を示 すが，それらの式は圧力(分圧) $p$ を濃度 $C$ に置き換え れば液相吸着にも適用できる。

\subsubsection{Langmuir $の$ 吸着式}

分子吸着モデルの中で, 最も簡単なものは Langmuir が活性炭へのガスの平衡吸着量を記述するために導い た吸着式である。この理論は，吸着理論の中で最も基 本的かつ重要なもので, 後述の BET 式や GAB 式もこ れを拡張したモデルである。

Langumuir 理論の前提は，次の 2 つである.

(1)吸着サイトの最大数が決まっている (吸着の飽和性).

(2)任意の分子が吸着する際の相互作用 (吸着エネル ギー）は，午の時点で吸着されている分子数には依 存しない。

単分子層吸着の場合，吸着質と吸着骫との相互作用 の大きさは吸着分子数に関わらず一定と見なせるので, 前提(2)は満たされる。よって，Langmuir 吸着式を単分 子吸着のための式と書いてある教科書もよくある。し かし，理論式の誘導から，必ずしも単分子吸着である 必要性はなく，吸着質 - 吸着剤の相互作用の大きさが 一定であることが本質的である。こうした前提に基づ いて導かれた Langmuir 式は，

$$
W=W_{\mathrm{s}} K p /(1+K p)
$$

とかかれる。ここで， $K$ は吸着の強さ（親和性）を表 すパラメータで， $K$ が大きい程，吸着質と吸着剤との 親和性が大きい。 また， $p$ は気相中の吸着質の圧力， $W$ は吸着剤単位重量（または単位体積）当たりの吸着質 の吸着量, $W_{\mathrm{s}}$ は飽和吸着量である。(6) 式を図示すると, $p \rightarrow \infty て ゙ W \rightarrow W_{\mathrm{s}}$ に漸近する双曲線となる.

Langmuir 式が適用される例としては，活性炭へのガ 又吸着の他に，気液界面へのタンパク質の吸着，高分 子電解質へのカルシウムイオンの吸着などが挙げられ る. 食品への水分収着の場合, 通常, 飽和吸着量は存 在しないので, 低圧下を除いて Langmuir 式は合わない. 


\subsubsection{BET (Brunauer, Emmett, Teller) の吸 着式}

Langmuir 式を多層吸着に拡張したのが Brunauer, Emmett, Tellerであり，導かれた式をその 3 人の研究 者の頭文字をとって BET の吸着式という。BETの吸着 式には有限層のものと無限層のものとがあるが，ここ では無限層の吸着式をのみ紹介する，BET 理論の前提 は次の 2 つである.

(1)単分子吸着層 (Langmuir 式と同様) の上に凝縮 (液化) 層が存在している

(2)第 2 層以上の吸着熱はすべて液体の凝縮熱（水分収 着の場合は純水）に等しい.

つまり，BET 理論においては，吸着剂に強く結合し た単分子層の上に吸着剤との相互作用がほとんどない 吸着分子が積み重なっているというモデル化がなされ ている。この前提の基に導かれる BET の吸着式は,

$$
W=\frac{C W_{\mathrm{m}} p}{\left(p_{0}-p\right)\left\{1+(C-1) p / p_{0}\right\}}=\frac{C W_{\mathrm{m}} a_{\mathrm{w}}}{\left(1-a_{\mathrm{w}}\right)\left\{1+(C-1) a_{\mathrm{w}}\right\}}
$$

となる．ここで， $C \equiv \kappa / \kappa_{v}(\kappa$ は単分子層での吸着の強 さを表すパラメータ， $\kappa_{v}$ は第 2 層以上での吸着の強さ を表すパラメータ), $p$ は吸着ガスの圧力, $p_{0}$ は吸着ガ スの飽和蒸気圧， $W$ は単位重量当たりの吸着量， $W_{\mathrm{m}}$ は 単分子層吸着における飽和吸着量である。BET式に特 徵的なパラメータは $C$ で，単分子吸着熱と気体の凝縮 熱の比を表している.

BET 吸着式は, 食品の水分収着現象を $a_{w}$ が 0 から 0.35 （試料によっては 0.50）程度まで記述可能である.

\subsubsection{GAB (Guggenheim-Anderson-de \\ Boer）吸着式}

BET 理論においては，単分子吸着層以外の吸着分子 は固体と相互作用をしないと仮定している。しかし， 食品で収着している水などが固体と全く相互作用をし ないというのは考えゔらい。そうした第 2 層以上の水 と固体との相互作用を考慮してBET式を補正したのが, GAB (Guggenheim-Anderson-de Boer) 吸着式である. この式は，食品の水分収着現象を記述するのに優れて おり，試料によっては $a_{\mathrm{w}}$ が 0.9 近くまで適用可能であ る. $\mathrm{GAB}$ 吸着式を水分活性 $a_{\mathrm{w}}$ を用いて書くと,

$$
W=\frac{C W_{\mathrm{m}} k a_{\mathrm{w}}}{\left(1-k a_{\mathrm{w}}\right)\left\{1+k(C-1) a_{\mathrm{w}}\right\}}
$$

となる。ここで, $C, W_{\mathrm{m}}$ は BET 吸着式と同様のパラメー 夕, $k$ は $0<k \leqq 1$ 值をとる定数である. $k$ の物理的意味は, 水と固体との相互作用の結果，第 2 層以上の水の凝縮 熱が純水の液化熱より小であるとした時の補正係数で ある. $k=1$ の時, $\mathrm{GAB}$ 吸着式は BET 吸着式に一致する.

Fig. 1 に米粉の水分収着等温線を $\mathrm{GAB}$ 式で回帰したも

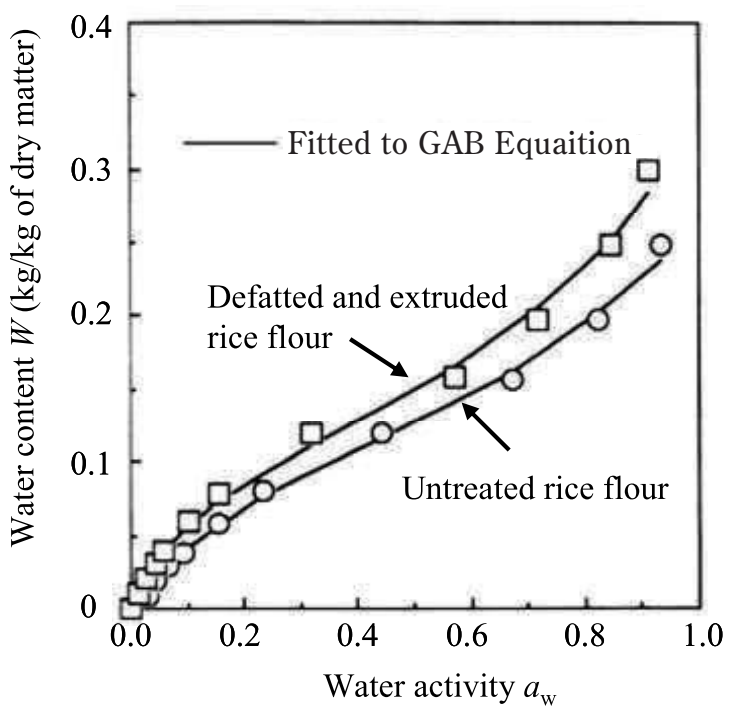

Fig. 1 Water sorption isotherm of rice flour.

The fitting parameters are: $W_{\mathrm{m}}=0.115 \mathrm{~kg} / \mathrm{kg}$ of dry matter, $C=7.97$, and $k=0.60$ for untreated rice flour $(\bigcirc) ; W_{\mathrm{m}}=0.116$ $\mathrm{kg} / \mathrm{kg}$ of dry matter, $C=11.47$, and $k=0.67$ for defatted and extruded rice flour $(\square)$.

のを示す [5,7]. 高水分活性域までよく回帰できている ことがわかる.

以上，食品の水分収着等温線の解析に用いられる代 表的な分子吸着モデル式である，Langmuir の吸着等温 式，BET式，GAB 式に関して簡単に述べてきた。これ らの式は，水分子と固体との相互作用に関して異なる 仮定が扔かれている．ただ，これらのモデル（理論） に共通することは，「水の束縛状態」は評価されている が，水分収着に伴う固体側の変化は考えられていない ということである。実際の食品の水分収着等温線は, 水分収着に伴う固体の変化も反映しているはずである. これが，高水分活性領域 $\left(a_{\mathrm{w}}>0.9\right)$ では，分子吸着乇 デルによる計算值が実測值と合わなくなる理由と考え られる。

\section{3 水分収着等温線の溶液熱力学による解析 $[6,7]$}

水分収着等温線から，水と固体の相互作用について 定量的な情報を得るには熱力学的解析が有効である. 水分収着等温線の解析は多くの場合, 水の化学ポテン シャルを対象とし，Clausius-Clapeyronの式に基づい て行われてきた (吸着熱力学とする). 吸着熱力学では, 水の束縛状態のみを考え，固体側の変化は取り扱わな い。しかし，食品の水分収着過程においては固体も変 化（膨潤など）する。一方，Gibbs-Duhem 式に基づく 溶液熱力学は，水のみでなく固体の化学ポテンシャル も対象とするので，水分収着に伴う固体側の変化を評 価できる、溶液熱力学を用いると，水分収着等温線の データから，自由エネルギー，エンタルピー，エント ロピーが求められる [7]が，ここでは自由エネルギーに 
関してのみ述べる.

溶液熱力学に打いては，(1) 式の水の化学ポテンシャ ル $\mu_{\mathrm{w}}^{\mathrm{s}}$ に加えて, 次式のように固体の化学ポテンシャル が定義される.

$$
\mu_{\mathrm{a}}^{\mathrm{s}}=\left(\frac{\partial \widetilde{G}^{\mathrm{s}}}{\partial m_{\mathrm{a}}}\right)_{T, P, m_{\mathrm{w}}}
$$

また，この固体の化学ポテンシャルを用いて以下のよ うに固体の自由エネルギー変化 $\Delta G_{\mathrm{a}}^{\mathrm{s}}$ を定義する.

$$
\Delta G_{\mathrm{a}}^{\mathrm{s}}=\mu_{\mathrm{a}}^{\mathrm{s}}-\mu_{\mathrm{a}}^{*}
$$

ここで， $\mu_{\mathrm{a}}^{*}$ は $T, P$ における純固体の化学ポテンシャ ルである

溶液熱力学に打ける基本式である Gibbs-Duhem 式 より，（9）式の $\Delta G_{\mathrm{a}}^{\mathrm{s}}$ は以下のように与えられる.

$$
\Delta G_{\mathrm{a}}^{\mathrm{s}}=-R T \int_{0}^{a_{\mathrm{w}}} \frac{W}{a_{\mathrm{w}}} d a_{\mathrm{w}}
$$

オイラーの同次式に関する定理より，質量 $m_{\mathrm{w}}$ の純水 のギブスの自由エネルギーは $m_{\mathrm{w}} \mu_{\mathrm{w}}^{*}$, 質量 $m_{\mathrm{a}}$ の純固体 のギブスの自由エネルギーは $m_{\mathrm{a}} \mu_{\mathrm{a}}^{*}$, 溶液のギブスの自 由エネルギーは $\widetilde{G}^{\mathrm{s}}=m_{\mathrm{w}} \mu_{\mathrm{w}}^{\mathrm{s}}+m_{\mathrm{a}} \mu_{\mathrm{a}}^{\mathrm{s}}$ である.よって, 質 量 $m_{\mathrm{w}}$ の水が質量 $m_{\mathrm{a}}$ の固体に収着した際のギブスの自 由エネルギー変化は $\left(m_{\mathrm{w}} \mu_{\mathrm{w}}^{\mathrm{s}}+m_{\mathrm{a}} \mu_{\mathrm{a}}^{\mathrm{s}}\right)-\left(m_{\mathrm{w}} \mu_{\mathrm{w}}^{*}+m_{\mathrm{a}} \mu_{\mathrm{a}}^{*}\right)$ で，(3) 式と（10）式を用いると（ $W$ は乾物基準の含水率 なので $\left.m_{\mathrm{w}} / m_{\mathrm{a}}=W\right)$,

$$
\begin{gathered}
\left(m_{\mathrm{w}} \mu_{\mathrm{w}}^{\mathrm{s}}+m_{\mathrm{a}} \mu_{\mathrm{a}}^{\mathrm{s}}\right)-\left(m_{\mathrm{w}} \mu_{\mathrm{w}}^{*}+m_{\mathrm{a}} \mu_{\mathrm{a}}^{*}\right) \\
=m_{\mathrm{w}} \Delta G_{\mathrm{w}}^{\mathrm{s}}+m_{\mathrm{a}} \Delta G_{\mathrm{a}}^{\mathrm{s}} \\
=m_{\mathrm{a}}\left(W \Delta G_{\mathrm{w}}^{\mathrm{s}}+\Delta G_{\mathrm{a}}^{\mathrm{s}}\right)
\end{gathered}
$$

となる。ここで積算ギブス自由エネルギー変化 $\Delta G^{\mathrm{s}}$ を 以下のように定義する.

$$
\Delta G^{\mathrm{s}}=W \Delta G_{\mathrm{w}}^{\mathrm{s}}+\Delta G_{\mathrm{a}}^{\mathrm{s}}
$$

(12) 式，（13) 式から， $\Delta G^{\mathrm{s}}$ は，単位質量の固体への水 分収着に伴うギブスの自由エネルギー変化であり，熱 力学的観点から, 固体と水との相互作用の大きさを評 価するのに適したパラメータであることがわかる. $(12) ，(13)$ 式から，W $\Delta G_{\mathrm{w}}^{\mathrm{s}}$ と $\Delta G_{\mathrm{a}}^{\mathrm{s}}$ はそれぞれ，ギブス の自由エネルギー変化への，水側の寄与，固体側の寄 与ということになる。もし，固体が水分収着によって 膨潤などの変化をする場合には, $\Delta G^{\mathrm{s}}$ に対して, $\Delta G_{\mathrm{a}}^{\mathrm{s}}$ が $\Delta G_{\mathrm{w}}^{\mathrm{s}}$ よりも大きく寄与する.

Fig. 1 の米粉の水分収着等温線を溶液熱力学により解 析して得られる $W \Delta G_{\mathrm{w}}^{\mathrm{s}}, \Delta G_{\mathrm{a}}^{\mathrm{s}}, \Delta G^{\mathrm{s}}$ の含水率依存性を Fig. 2 に示す. 水側の自由エネルギーに関して $W \Delta G_{\mathrm{w}}^{\mathrm{s}}$ がプロットしてあるのは, $\Delta G^{\mathrm{S}}$ への水の変化の寄与を 明確にするためである。Fig. 1 に打いては，水分活性值 が同じ場合，水分収着量は，脱脂打よびエクストルー ダ処理した米粉の方が未処理の米粉に比べて大きく, (a) Untreated rice flour

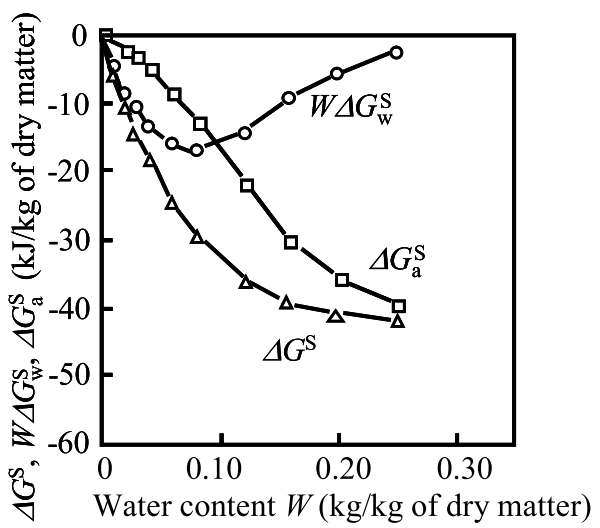

(b) Defatted and extruded rice flour

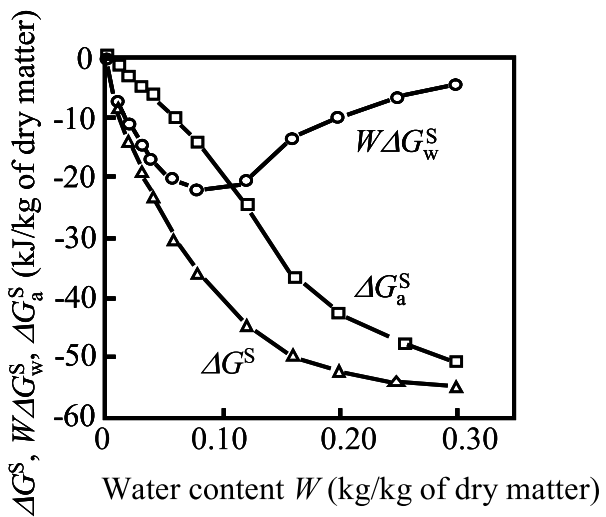

Fig. 2 Dependence of Gibbs free energy values $W \Delta G_{\mathrm{w}}^{\mathrm{s}}, \Delta G_{\mathrm{a}}^{\mathrm{s}}$, and $\Delta G^{\mathrm{s}}$ on water content for rice flour.

$\Delta G_{\mathrm{w}}^{\mathrm{s}}$ : The difference between the chemical potential of water in a solution and that of pure water.

$\Delta G_{\mathrm{a}}^{\mathrm{s}}$ : The difference between the chemical potential of solid in a solution and that of a pure solid.

$\Delta G^{\mathrm{s}}\left(=W \Delta G_{\mathrm{w}}^{\mathrm{s}}+\Delta G_{\mathrm{a}}^{\mathrm{s}}\right):$ change in the integral value of Gibbs free energy by water sorption.

処理によって水との親和性が向上していることがうか がわ机る. Fig. 2 において，脱脂打よびエクストルーダ 処理した米粉の $\Delta G^{\mathrm{s}}$ の絶対值は，同じ含水率では，未 処理の米粉の值より大きい。（12），(13）式に示したよ うに, $\Delta G^{\mathrm{s}}$ は単位質量の固体への水分収着に伴うギブ スの自由エネルギー変化であり，固体と水との親和性 の程度とみなすことができる。つまり， $\Delta G^{\mathrm{s}}$ によって 米粉の水との親和性の改質の程度が定量的に評価でき ることを意味する．また， $\Delta G^{\mathrm{s}}$ への水側の寄与 $W \Delta G_{\mathrm{w}}^{\mathrm{s}}$ は極小をとり，高含水率では 0 に漸近している．この ことは，高含水率に扎いては，積算自由エネルギー変 化 $\Delta G^{\mathrm{s}}$ に対して，固体側の変化 $\Delta G_{\mathrm{a}}^{\mathrm{s}}$ の寄与が大きいこ とを意味する.

以上のように, $\Delta G^{\mathrm{s}}$ は, 熱力学的観点から, 固体と 水との相互作用の大きさを評価するのに適したパラ メータである、筆者らは， $\Delta G^{\mathrm{s}}$ を用いて変性や化学修 飾によるタンパク質の水との親和性の変化，高吸水性 
ポリマーの親水性の評価などを行った [8-11]. ただ, そうした研究に関わっていた当時は, $\Delta G^{\mathrm{s}}$ が固体と水 との相互作用の大きさを評価するのに最適な $\left(a_{\mathrm{w}}\right.$ より) パラメータで, $W \Delta G_{\mathrm{w}}^{\mathrm{s}}$ や $\Delta G_{\mathrm{a}}^{\mathrm{s}}$ は $\Delta G^{\mathrm{s}}$ への寄与項ととら えていた．

\section{3. 食品のガラス転移}

\subsection{2 成分系状態図とガラス転移}

ガラス転移を理解するために重要な糖一水などの食 品の 2 成分状態図について簡単に述べる。こうした 2 成分状態図は, ガラス転移のみでなく, 凍結, 乾燥, 凍結操作など水の関わる食品の製造プロセスや保存を 考えるうえでも非常に重要である．2 成分状態図に関す るより詳しい説明は文献 $[5,6]$ を参照されたい.

Fig. 3 の上図に典型的な食品の 2 成分状態図を，Fig. 3 の下部には, 食品の内部構造の概要を, 状態図と対応 させて示す.

高含水率で冷却により水結晶を生成する試料は，Fig. 3 の点線の左側にあると考えてよい. そして, 凍結物は, 水結晶と溶質と未凍結水を含む濃厚非晶質溶液 (Concentrated Amorphous Solution, CASという) と 呼ばれる 2 相構造となっている。 そして, 凍結物は, $T_{\mathrm{g}}{ }_{\mathrm{g}}$ 以下の温度で CAS 部がガラス化しており, 凍結前の試 料濃度 $C$ が変化しても CAS 部の濃度は $C_{\mathrm{g}}{ }^{\prime}$ で一定であ る(水結晶の割合が試料濃度によって変化する)。つま り, 食品を冷却・凍結する場合, $T{ }_{\mathrm{g}}$ 以下の温度では, 試料の状態は, 水結晶と濃度 $C_{\mathrm{g}}{ }^{\prime}$ の CAS 部から成り, Fig. 3 の” Ice \& Glass”とかかれた領域にあると考え
てよい。そうした“Ice \& Glass”の状態にある試料を 昇温させると, 温度 $T^{\prime}{ }_{\mathrm{g}}$ に扎いて CAS 部がラバーに変 化し，系は“Ice \& Rubber”の状態になる。

一方，低含水率の食品を急冷（もしくは溶融状態の まま乾燥) させた場合, 試料は一相のガラスとなる (べっ こう飴など)。そうしたガラスは，Fig. 2 における $C_{\mathrm{g}}$ ' 以上の濃度での “Glass” の領域に属する。 そうしたガ ラスを昇温すると，矢印ヤで示したように曲線（ガラ ス転移の場合, 平衡線ではない) を横切る時にラバー に変化する。 これが，高濃度の系で観測されるガラス 転移であり, 曲線を横切る時の温度がガラス転移点 $T_{\mathrm{g}}$ である. ガラス転移点 $T_{\mathrm{g}}$ の濃度依存性を示す曲線から, ガラス転移点 $T_{g}$ は濃度の減少（含水率の増加）ととも に低下することがわかる，これは，水によって試料が 可塑化 (plasticize) することによって $T_{\mathrm{g}}$ が低下するた めで, 水は食品の最も重要な可塑㓮（plasticizer）とい われる. 実際, 水などの添加物の可塑化の効果を, DSC (Differential Scanning Calorimetry; 示差走査熱量 測定）によって測定される $T_{\mathrm{g}}$ の低下の程度によって評 価することが多い. 低含水率の食品には, キャンディー, クッキー, 乾燥したパスタ, やシリアルなどガラス状 のものが多いが，そうした食品のガラス転移は，Fig. 3 の状態図における高濃度（低含水率）側の曲線によっ て議論される.

\section{2 低含水率食品のガラス転移 [12]}

上述のように，ガラス状物質の温度を上昇させると， ガラス転移点 $T_{\mathrm{g}}$ においてラバーに変化する． $T_{\mathrm{g}}$ は通常 DSCで測定される. Fig. 4 に, DSCで測定した小麦粉

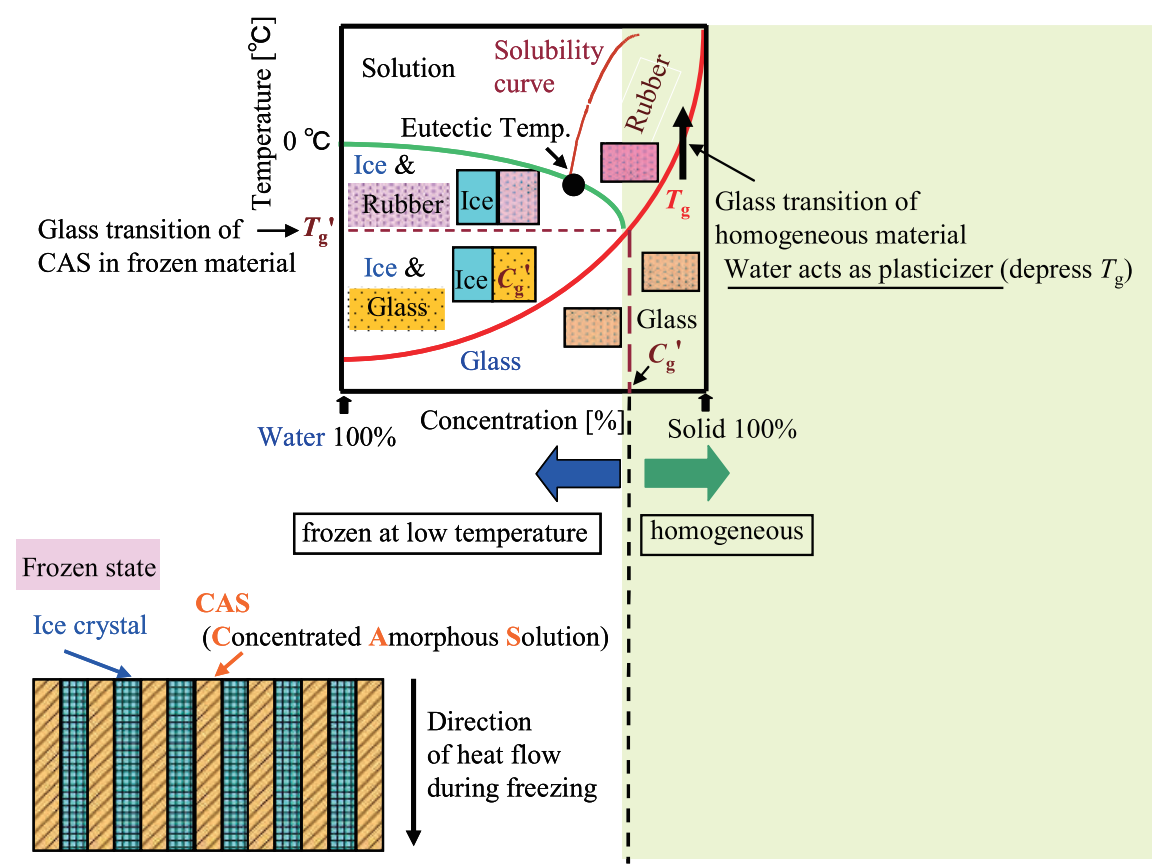

Fig. 3 Typical state diagram of 2-component system such as sugar solution. 
グルテンおよびのマルトデキストリンの $T_{\mathrm{g}}$ の含水率依 存性を示す。オンセットとは，DSC 測定に打いて観察 されるガラス転移の開始温度，オフセットとはガラス 転移の終了温度である。通常，オンセット温度とオフ セット温度の中点 (mid-point) をガラス転移点 $T_{\mathrm{g}}$ と する. 含水率の増加とともに $T_{g}$ は低下しているが，こ れは水の可塑化効果によると考えられる。 このことか ら，特定の試料に対する水の可塑劑としての効果を定 量的に評価する場合，Fig. 4 に示すような含水率上昇に 伴う $T_{\mathrm{g}}$ の低下の程度が指標とされる.

一方，一定温度でガラス状食品を加湿（水分収着） した場合は，水の可塑化効果によってラバー化するは ずである. 例えば，Fig. 4 中に示したように， $20^{\circ} \mathrm{C} に お ~$ いては，グルテンは含水率 $W_{\mathrm{g}}=0.20 \mathrm{~kg} / \mathrm{kg}-\mathrm{dry}$ matter，マルトデキストリンは $0.165 \mathrm{~kg} / \mathrm{kg}$-dry matter

(a)

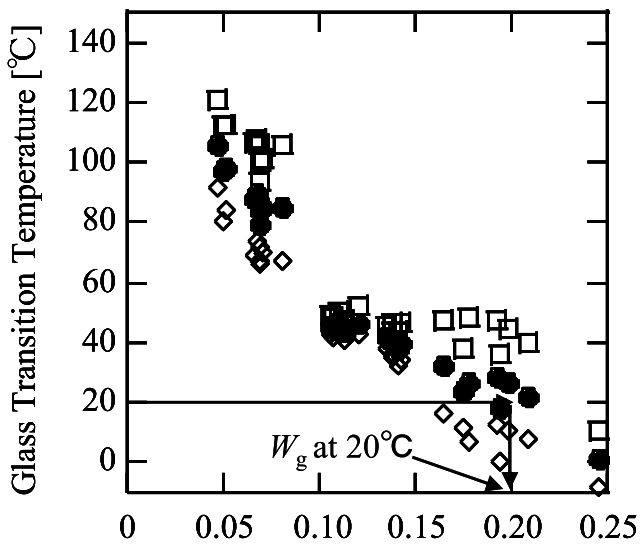

Water Content $W[\mathrm{~kg} / \mathrm{kg}$-dry matter $]$

(b)

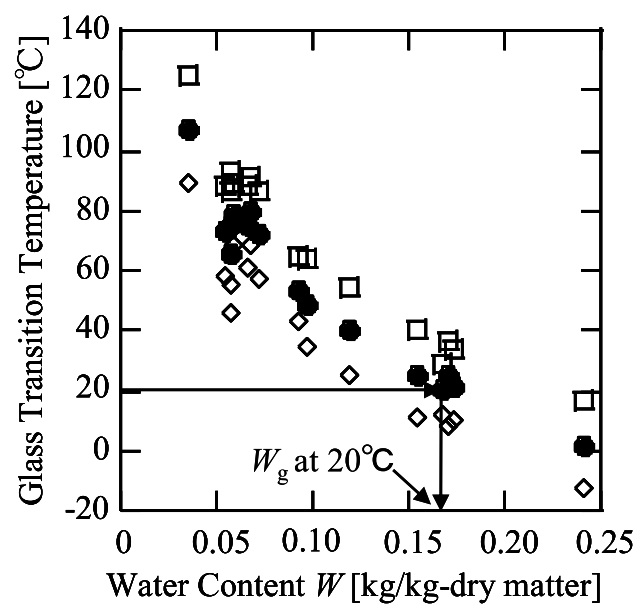

Fig. 4 Dependence of the glass transition temperature on Water Content for wheat gluten (a) and maltodextrin (b).

$\diamond$, onset; $\bullet$, mid-point $\left(T_{\mathrm{g}}\right)$; $\square$, offset

$W_{\mathrm{g}}$ : the water content at which the glass to rubber transition occurs at constant temperature.
以上でラバーになると推測できる.

Fig. 3 の状態図に打けるガラスとラバーの境界線は, 厳密には平衡線ではないので, Fig. 4 に示した（DSC のデータから算出した） $W_{\mathrm{g}}$ 以上で実際にラバー化して いるか確認が必要である。グルテンに関しては，ガラ スからラバーへの転移で色差変化 $\Delta E$ が増加すること

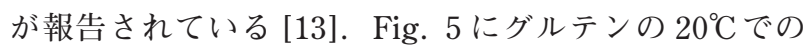
$\Delta E$ の含水率依存性を示す. Fig. 4 から求めた $W_{\mathrm{g}}=0.20$ $\mathrm{kg} / \mathrm{kg}$-dry matter 以上で $\Delta E$ の值が上昇しており, DSCのデータから求めた $W_{\mathrm{g}}$ 以上で試料がラバー化し ていることが確認できる.

\section{4. 食品の水分収着等温線とガラス転移 一可塑剤としての水 $[6,12]$}

上述のように，ガラスからラバーへの転移は，温度 の上昇だけでなく，含水率の上昇でも起こる. 水分収 着等温線の測定に打いても， ある含水率以上でガラス からラバーへ転移するはずである.

Fig. 6 に，ガラス状物質であるグルテンとマルトデキ ストリン（Fig. 4 と同様の試料）の $20^{\circ} \mathrm{C}$ に打ける水分 収着等温線を溶液熱力学による解析結果と共に示す. 図中には, $\Delta G_{\mathrm{w}}^{\mathrm{s}}, \Delta G_{\mathrm{a}}^{\mathrm{s}}, \Delta G^{\mathrm{s}}$ の含水率 $(W)$ 依存性の他に, $W$ と $a_{\mathrm{w}}$ の関係（水分収着等温線の逆関数）も実線で示 してある。また図中には，GAB 式に回帰して求めた単 分子吸着量 $W_{\mathrm{m}}$, Fig. 4 の DSC 測定結果から算出した ラバーへ転移する含水率 $W_{\mathrm{g}}$ も記入してある. $\Delta G^{\mathrm{s}}$ への 水の寄与である $W \Delta G_{\mathrm{w}}^{\mathrm{s}}$ は $W_{\mathrm{m}}$ の近辺の含水率で極小を 示し，固体側の自由エネルギー変化の変化 $d\left(\Delta G_{\mathrm{a}}^{\mathrm{s}}\right) / d W$ が緩やかになる高含水率の領域でラバーへの転移がみ られる。

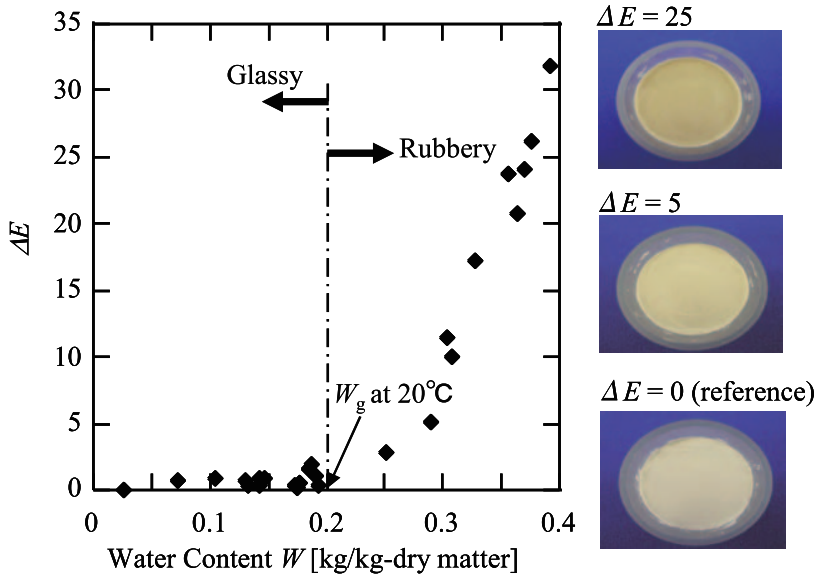

Fig 5 Dependence of Colour change $(\Delta E)$ on Water Content $(W)$ for Wheat Gluten at $20^{\circ} \mathrm{C}$.

$W_{\mathrm{g}}$ : the water content at which the glass to rubber transition occurs. 
(a)

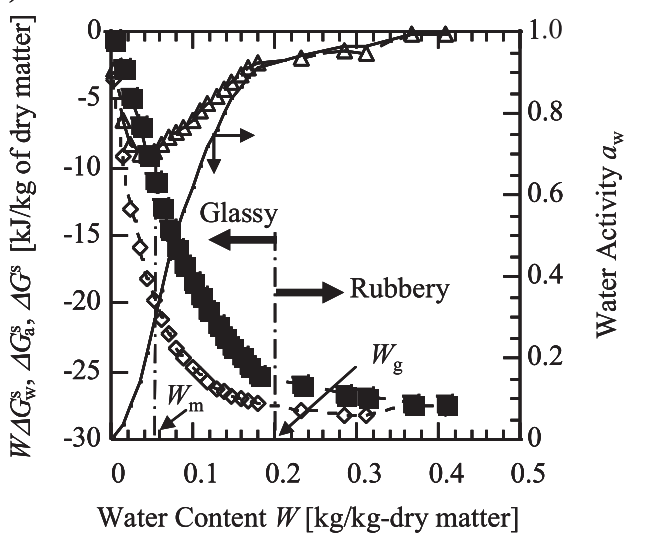

(b)

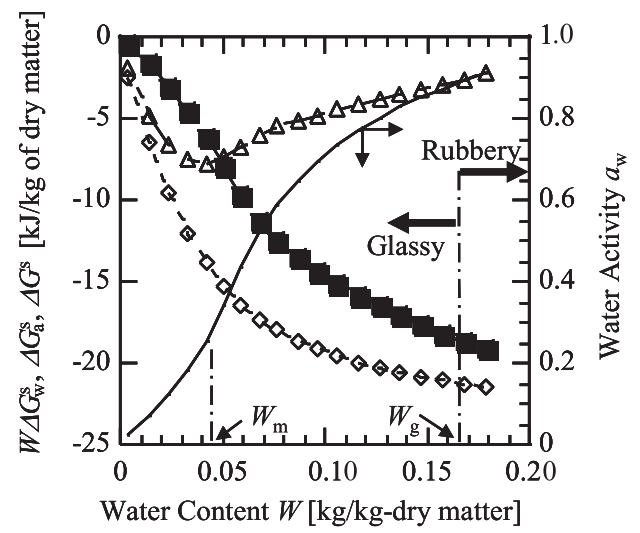

Fig. 6 Dependence of Gibbs free energy values $W \Delta G_{\mathrm{w}}^{\mathrm{s}}$, $\Delta G_{\mathrm{a}}^{\mathrm{s}}$, and $\Delta G^{\mathrm{s}}$ on water content for wheat gluten (a) and maltodextrin (b).

$\triangle, W \Delta G_{\mathrm{w}}^{\mathrm{s}} ; \mathbf{\square}, \Delta G_{\mathrm{a}}^{\mathrm{s}} ; \diamond, \Delta G^{\mathrm{s}}$

$W_{\mathrm{g}}$ : the water content at which the glass to rubber transition occurs at $20^{\circ} \mathrm{C}$.

$W_{\mathrm{m}}$ : Monolayer water content

(a) $W_{\mathrm{m}}=0.0587 \mathrm{~kg} / \mathrm{kg}$ of dry matter, $C=9.07, k=0.75$

(b) $W_{\mathrm{m}}=0.0445 \mathrm{~kg} / \mathrm{kg}$ of dry matter, $C=8.36, k=0.83$

吸湿により $T_{\mathrm{g}}$ の值は低下するが，Fig. 4 の小麦粉グ ルテンとマルトデキストリンのデータから求めた $T_{\mathrm{g}}$ の 低下の程度 $\Delta T_{\mathrm{g}}\left(\equiv T_{\mathrm{g}}-T_{\mathrm{g} 0} ; T_{\mathrm{g} 0}\right.$ は $\mathrm{CaSO}_{4}$ 共存下で $105^{\circ} \mathrm{C}$ で 48 時間，真空加熱乾燥した試料のガラス転移温度） と Fig. 5 の $\Delta G_{\mathrm{a}}^{\mathrm{s}}$ との関係を Fig. 7 に示す. 含水率の増 加に伴うガラス転移点の低下 $\Delta T_{\mathrm{g}}$ と $\Delta G_{\mathrm{a}}^{\mathrm{s}}$ には高い相関 がみられる。

$\Delta T_{\mathrm{g}}$ と $\Delta G_{\mathrm{a}}^{\mathrm{s}}$ に高い相関がある理由について考えてみ る. $\Delta G_{\mathrm{a}}^{\mathrm{s}}$ は $(12)$ 式から，水分収着による伴う固体の 化学ポテンシャル $\mu_{\mathrm{a}}^{\mathrm{s}}$ の変化（純固体の化学ポテンシャ ル $\mu_{\mathrm{a}}^{*}$ との差) である. 固体の化学ポテンシャルにより, 水分収着に伴う膨潤・軟化など高分子の変化の程度が 評価されることは既に述べた。つまり， $\Delta G_{\mathrm{a}}^{\mathrm{s}}$ の挙動は 水の可塑化効果による固体の変化を反映しているとい える. 水の可塑化効果によって, ガラス転移点は下がり, $\Delta T_{\mathrm{g}}$ は増大する，その結果， $\Delta G_{\mathrm{a}}^{\mathrm{s}}$ は $\Delta T_{\mathrm{g}}$ と高い相関を (a)

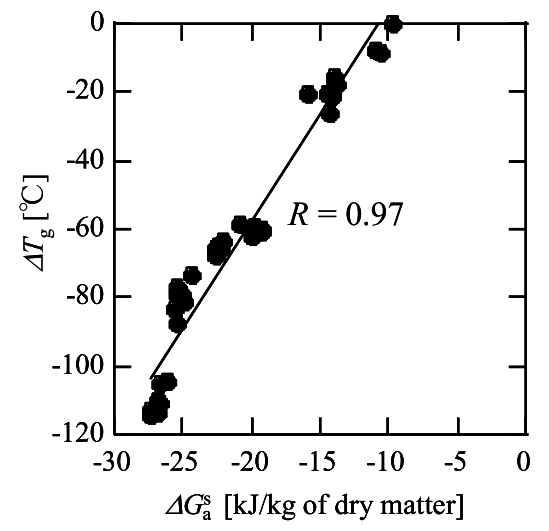

(b)

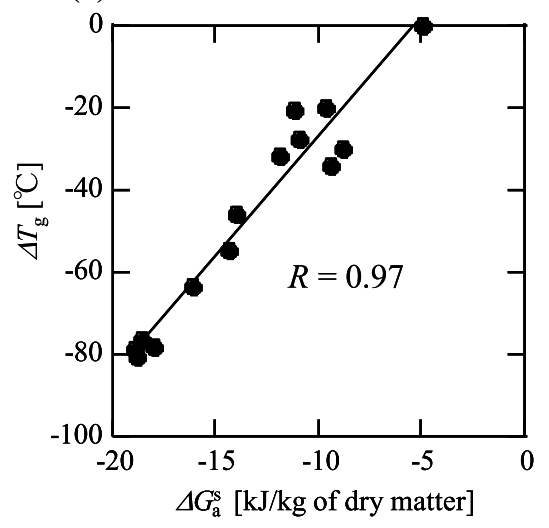

Fig. 7 Correlation between $\Delta G_{\mathrm{a}}^{\mathrm{s}}$ and $\Delta T_{\mathrm{g}}$ of wheat gluten (a) and maltodextrin (b).

$R$ : correlation coefficient $\Delta T_{\mathrm{g}} \equiv T_{\mathrm{g}}-T_{\mathrm{g} 0}$ where $T_{\mathrm{g} 0}$ is $T_{\mathrm{g}}$ of dried sample.

(a) $T_{\mathrm{g} 0}=105.7^{\circ} \mathrm{C}$ at $W=0.047 \mathrm{~kg} / \mathrm{kg}$ of dry matter

(b) $T_{\mathrm{g} 0}=106.9^{\circ} \mathrm{C}$ at $W=0.035 \mathrm{~kg} / \mathrm{kg}$ of dry matter

示したと考えられる. 言い換えると, Fig. 7 の結果は, 水によるガラス状食品の可塑化効果を水分収着等温線

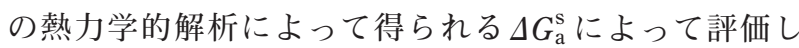
うることを意味している.

\section{5. 水分活性とガラス転移}

最後に水分活性（水分収着等温線）とガラス転移の 関係についてまとめてみよう．水分活性 $a_{\mathrm{w}}$ は，（2）式 が示すように水の化学ポテンシャルと対応するので, 食品中での水の “束縛状態”を評価しているといえる. 水分収着等温線の解析に用いられる $\mathrm{GAB}$ 式などの分子 吸着モデルは，単分子吸着量，水と固体の相互作用を 表すパラメータを求めることはできるが，水分収着に よる固体の変化は前提にない.

一方，ガラス転移は，「ガラスからラバーへ」という 試料の物性変化であり，水はあくまで $T_{\mathrm{g}}$ を低下させる 可塑剤として扱わ机る。 つまり，水分活性，ガラス転 
移は共に，食品の保存性あるいは物性と水との関係を 解析可能な理論だが，水と固体の扱いが異なっている.

食品中の固体の状態は水分収着によって変化するは ずで，水分収着等温線のデータは，水の束縛状態と固 体側の状態変化の両方を反映しているはずである。水 分収着等温線を熱力学的に解析することにより，水と 固体の相互作用に関するパラメータが求められるが, 吸着熱力学からは水側の情報しか得られない. しかし, 溶液熱力学は, 固体側の化学ポテンシャルを算出でき るため，水分収着等温線のデータから固体側の変化に 関する情報を引き出すことが可能になる。 上述のよう に，固体側の自由エネルギー変化 $\Delta G_{\mathrm{a}}^{\mathrm{s}}$ は，水分収着に 伴う固体側の変化を反映して打り，Fig. 7 に示すように 水分収着に伴うガラス転移点の低下 $\Delta T_{\mathrm{g}}$ との相関も高 い. 水分収着等温線は水の束縛状態と固体側の状態変 化の両方を反映し，含水率によってガラスからラバー とに分かれているはずであり，それに溶液熱力学を適 用することにより，水分活性とガラス転移の関係がみ えてくる.

\section{6. おわりに}

水分収着等温線の熱力学的研究に初めて関わった数 年後にガラス転移の研究テーマを手掛けたときは，「な ぜ，食品科学の教科書の水分活性の項にガラス転移の ことがかかれていないのか」が不思議でならなかった. 水分収着等温線（含水率 $v s . a_{\mathrm{w}}$ ）の測定をすれば，試料 がガラスからラバーに変化することが観察されるにも 関わらずである。本稿で述べたように，溶液熱力学は， 水分収着等温線から水の束縛状態, 固体の変化の両方 に関する情報を引き出すことができるので，水分活性 と水の可塑化によるガラスからラバーへの転移を結び つけることができる，と現在の筆者は考えている。

\section{謝辞}

筆者が，水分活性，ガラス転移という食品科学・工 学上，極めて重要な 2 つ理論に関する研究に携わる ことができたのは，大変幸運だったと思う，共に研究 に参加していただきご指導ご鞭撻をいただきました諸 先生方, 共同研究者, 学生の皆さんに, 深く感謝申し 上げます。

\section{References}

1) H. Kumagai, H. Kumagai, T. Hagiwara; "Physical Properties of Foods and Effect of Water on Them I Physical Properties and Water in Food Engineering” (in Japanese), Jap. J. Food Eng., 9, 79-89 (2008).
2) H. Kumagai; "Physical Properties of Foods and Effect of Water on Them II Electric Properties and Dielectric Relaxation” (in Japanese), Jap. J. Food Eng., 9, 123-134 (2008).

3) H. Kumagai, H. Kumagai; "Physical Properties of Foods and Effect of Water on Them III Analysis of Molecular Mobility in Glassy and Rubbery Foods by Electric and Pulse-NMR Measurements” (in Japanese), Jap. J. Food Eng., 9, 197-206 (2008).

4) H. Kumagai, H. Kumagai; Physical Properties of Foods and Effect of Water on Them, V Rheology and Food Engineering (in Japanese), Jap. J. Food Eng., 10, 137-148 (2009).

5) H. Kumagai, H. Kumagai, M. Takada; "Introduction of Food Engineering-Manufacture and Preservation (Shokuhinkogaku nyumon-Shokuhin seizo to hozon no kanngaekata)” , I \& K Corporation, Tokyo, Japan, 2005.

6) H. Kumagai; Analysis of Physical Properties of Foods Relating to Water and Their Application (in Japanese), Jap. J. Food Eng., 18, 1-18 (2017).

7) H. Kumagai, M. Iwase, H. Kumagai, A. Mizuno, T. Yano; Aplication of Solution Thermodynamics to Water Sorption Isotherms of Food materials, Biosci. Biotechnol. Biochem., 58, 475-481 (1994).

8) H. Kumagai, A. Mizuno, H. Kumagai, T. Yano; Analysis of Water Sorption Isotherms of Superabsorbent Polymers by Solution Thermodynamics, Biosci. Biotechnol. Biochem., 61, 936-94 (1997).

9) H. Kumagai, Y. Norimatsu, N. Hashizume, H. Sakurai, H. Kumagai; Deamidation of Wheat-flour Gliadin with Ionexchange Resin (in Japanese), J. Jpn. Soc. Food Sci. and Technol. (Nippon Shokuhin Kagaku Kogaku Kaishi), 48, 884-890 (2001).

10) Y. Norimatsu, H. Kumagai, R. Nagai, H. Sakurai, H. Kumagai; Deamidation of Wheat-flour Gluten with Ionexchange Resin and Its Functional Properties (in Japanese), J. Jpn. Soc. Food Sci. and Technol. (Nippon Shokuhin Kagaku Kogaku Kaishi), 48, 639-645 (2002).

11) H. Kumagai, H. Seto, H. Sakurai, K. Ishii, H. Kumagai; Analysis of Water Sorption Behavior of Native and Denatured Proteins by Solution Thermodynamics, Biosci. Biotechnol. Biochem., 61, 1307-1311 (1997).

12) E. Shimazaki, A. Tashiro, H. Kumagai, and H. Kumagai; Analysis of Water Sorption Isotherms of Amorphous Food Materials by Solution Thermodynamics with Relevance to Glass Transition: Evaluation of Plasticizing Effect of Water by the Thermodynamic Parameters, Biosci. Biotech. Biochem., 81, 743-749 (2017).

13) Y. Fujio and J. Lim; Correlation between the glass-transition 
point and color change of heat-treated gluten. Cereal Chem., 66, : 268-270 (1989).

\section{要旨}

食品の水分活性とガラス転移に関して概説した。水 分収着等温線は，食品中の水と固体成分の相互作用に 関する情報を与える。水分収着等温線を溶液熱力学を 用いて解析することにより，水と固体両方の熱力学的 パラメータが求められる。積算ギブス自由エネルギー
変化 $\Delta G^{\mathrm{s}}$ は熱力学的観点から, 固体と水との相互作用 の程度評価するのに適するパラメータである。水分収 着等温線の熱力学的解析によって得られるパラメータ と水分収着に伴うガラス転移温度 $\left(T_{g}\right)$ の低下には関 係がみられる。水分収着等温線から得られる熱力学的 パラメータ $\Delta G_{\mathrm{a}}^{\mathrm{s}}$ は $T_{g}$ の低下の程度 $\Delta T_{\mathrm{g}}\left(\equiv T_{\mathrm{g}}-T_{\mathrm{g} 0} ; T_{\mathrm{g} 0}\right.$ は乾燥試料の $T_{\mathrm{g}}$ ) と高い相関を示した。言い換えれば, 水のガラス状食品に対する可塑剤としての効果が $\Delta G_{\mathrm{a}}^{\mathrm{s}}$ により評価しうることになる。 